\title{
PEMBERDAYAAN IBU RUMAH TANGGA MELALUI PELATIHAN (3M) UNTUK MENINGKATKAN KESEJAHTERAAN KELUARGA
}

\author{
Anik Pujiati, Priarti Megawanti, Retariandalas
}

\author{
Program Studi Pendidikan Matematika Universitas Indraprasta PGRI \\ anikrahmany@yahoo.com
}

\begin{abstract}
Abstrak
Seorang ibu merupakan sosok multitalenta yang mempunyai pengaruh yang luar biasa besarnya dalam keluarga. Seorang ibu bisa mendidik generasinya menjadi manusia hebat jika sang ibu senantiasa belajar, sehingga bisa memberi perubahan pada keluarga. Pada kegiatan pengabdian masyarkat ini para ibu diberi pelatihan $(3 \mathrm{M})$ yaitu pelatihan dalam mengelola sampah, memanfaatkan lahan sempit dan membuat posdaya. Luaran pelatihan ini para ibu mendapatkan pengetahuan dan keterampilan sehingga bisa diaplikasikan dalam kehidupan nyata dan bisa memberikan perubahan sikap. Pelatihan dimulai dari pengelolaan sampah rumah tangga, kemudian mengolahnya menjadi produk bernilai yang pada pelatihan ini para ibu membuat karya hiasan dengan teknik decoupage, dilanjutkan dengan pengelolaan lahan sempit untuk menghasilkan tanaman produktif, terakhir dengan pembentukan pos pemberdayaan keluarga sebagai wadah untuk berkumpulnya para ibu dalam rangka peningkatan kualitas dan kesejahteraan keluarga.
\end{abstract}

Kata kunci : pengelolaan sampah berbasis masyarakat, teknik decoupage, pemanfaatan lahan sempit, pos daya

\begin{abstract}
Mother is a multitalented figure who has a wonderful influence in a family. Mother could teach her generation to become a great man if she continuously learns as she could bring a change in a family. In this community service activity, mothers are given a training (3M), that is, a training in waste management, narrow land use and a creation of family empowerment post. This training output is that mothers get insight and skill to be applied in real life and can give a change in attitude. The training begins from household's waste management, then process it to valuable product where mothers make products with decoupage technique, then it continues to narrow land use to produce productive greens. Lastly, the creation of family empowerment post as a media for mothers to gather in increasing the quality and family's wealth.
\end{abstract}

Key words: society's based waste management, narrow land use, family empowerment post

\section{PENDAHULUAN}

Delapan sasaran Millennium Development Goals (MDGs) yang telah disepakati oleh 189 Kepala Negara atau pemimpin dunia pada Sidang Umum PBB di New York yaitu 8 fungsi keluarga secara terpadu, utamanya fungsi agama atau Ketuhanan yang Maha Esa, fungsi cinta kasih, fungsi perlindungan, fungsi reproduksi dan kesehatan, fungsi pendidikan, fungsi sosial budaya, fungsi ekonomi atau wirausaha dan fungsi lingkungan. 
Penguatan fungsi-fungsi utama tersebut diharapkan memungkinkan setiap keluarga makin mampu membangun dirinya menjadi keluarga sejahtera, keluarga yang mandiri, dan keluarga yang sanggup menghadapi tantangan masa depan dengan lebih baik.

Masalah dan kebutuhan keluarga Indonesia makin berkembang. Kompleksitas masalah yang dihadapi juga bertambah tinggi. Padahal keluarga Indonesia belum berkembang dengan baik untuk mampu menyelesaikan masalah dan memenuhi kebutuhannya sendiri secara mandiri. Pembangunan manusia akan sangat efektif apabila dapat dilakukan dalam lembaga keluarga. Keluarga adalah lembaga utama, yang terdekat dan paling akrab dengan setiap anggotanya, juga merupakan lembaga terkecil dalam masyarakat. Keluarga yang bermutu dan kuat akan menjadi wahana pembangunan bangsa yang sangat efektif. Karena itu diperlukan dukungan pemberdayaan, pelayanan paripurna dan dinamis agar setiap keluarga dapat melaksanakan fungsi-fungsi utamanya dengan baik untuk membangun seluruh anggotanya. Apabila keluarga dapat berfungsi dengan baik, maka seluruh anak bangsa akan dapat dikembangkan menjadi sumber daya manusia yang beriman, bermutu, handal dan sanggup membangun negara dan bangsanya dengan baik. Hal tersebut yang mendasari pentingnya pemberdayaan Ibu rumah tangga karena seorang ibu mempunyai andil yang cukup besar dalam menciptakan fungsi keluarga dengan baik sehingga kesejahteraan keluarga Indonesia bisa tercapai. Program ini merupakan program untuk seluruh keluarga Indonesia termasuk di Perumahan Ambar Cibinong Residence.

\section{METODE PELAKSANAAN}

Metode yang akan digunakan dalam kegiatan ini adalah dengan memberikan penyuluhan dan pelatihan. Penyuluhan dilakukan dengan atraktif dan persuasif. Penyuluhan dilakukan atraktif supaya kegiatan tidak terkesan menggurui tetapi lebih pada sharing informasi sehingga tidak membuat bosan para ibu, seperti tanya jawab terkait materi, dan demonstrasi yaitu dengan terjun langsung menerapkan materi yang didapat. Persuasif di sini yaitu dengan cara mengajak peserta ikut serta dengan cara yang menyenangkan dan penayangan slide yang terkait dengan kegiatan. Sedangkan untuk materi mengolah sampah menjadi hasil karya dilakukan dengan pelatihan, jadi kita memberi materi kemudian ibu-ibu praktek membuat karya.

Peserta kegiatan adalah para ibuibu warga perumahan Ambar Cibinong Residence. Ibu-ibu komplek perumahan tersebut mempunyai agenda bulanan yaitu arisan, jadi pelaksanaan di sesuaikan dengan jadwal arisan. Ibu-ibu muda ini yang nantinya akan menerapkan materi yang didapat dari penyuluhan pada keluarga masing-masing dan lingkungan sekitarnya. Kegiatan ini bermanfaat agar ibu-ibu mempunyai wawasan yang lebih luas tentang pengelolaan sampah dan pemanfaatan lahan sempit untuk menjaga lingkungan sekaligus dapat meningkatkan gizi keluarga dan meningkatkan kesejahteraan keluarga.

Pada pelaksanaannya tahapan dan langkah-langkah kegiatan pengabdian masyarakat ini adalah sebagai berikut :

1. Tahap Persiapan

Tim Abdimas melakukan survei ke wilayah mitra yaitu Perumahan Ambar Cibinong Residence, Kelurahan Harapan Jaya, Kecamatan Cibinong, Kabupaten 
Bogor. Pada kegiatan ini, tim melakukan pertemuan dengan perwakilan tokoh masyarakat seperti RT dan tokoh wanita. Pada pertemuan ini dilakukan diskusi dan perencanaan pelaksanaan kegiatan. Dari diskusi diharapkan tim abdimas bisa mengetahui kapan waktu yang tepat dan teknis pelaksanaann dalam melaksanakan kegiatan pengabdian masyarakat.

2. Tahap Pelaksanaan

Metode yang digunakan dalam pelaksanaan kegiatan pengabdian masyarakat ini adalah penyuluhan atraktif dan demonstrasi dengan melalui beberapa tahapan sebagai berikut:

a. Presentasi dan Diskusi

Dalam kegiatan ini tim akan menjelaskan bagaimana mengelola sampah sehingga menjadi berkah untuk masyarakat khususnya bagi para ibu dengan membuat karya dari barang yang sudah usang/kurang bermanfaat menjadi barang yang bisa bermanfaat kembali misalnya sebagai hiasan dan penyampaian materi budidaya tanaman organik di lahan sempit.

b. Demonstrasi

Pada kegiatan ini dilakukan demonstrasi bagaimana cara-cara memilah sampah, membuat prakarya dari barang yang tidak terpakai menjadi barang yang memiliki nilai guna lebih tinggi dalam hal ini tim memperkenalkan teknik decoupage untuk menyulap barang-barang bekas menjadi hiasan dinding, selain itu teknik ini juga bisa diaplikasikan untuk membuat karya yang bisa dijual sehingga bisa meningkatkan pendapatan bagi para ibu rumah tangga. Selain itujua ada demontrasi dalam menanam tanaman organik di lahan sempit. Dalam prakteknya menanam sayuran organik dan buah tabulampot, sehingga walaupun sudah tidak ada lahan/tanah kosong bisa menggunakan pot atau pot kantong yang ditempel maupun digantung dalam menanam.

\section{HASIL DAN PEMBAHASAN}

Dalam kegiatan pengabdian masyakarat ini hasil yang dicapai adalah tumbuhnya pemahaman (kognitif), sikap (afektif), dan kebiasaan baik (psikomotorik) terhadap upaya menjaga kebersihan lingkungan. Hasil kegiatan ini lebih jauh yaitu meningkatkan keterampilan para ibu dalam mengelola sampah, keterampilan membuat karya yang bisa menambah nilai guna suatu barang sehingga bisa meningkatkan pendapatan sampingan, dan keterampilan dalam memanfaatkan lahan sempit dengan menanam sayuran/toga/ tabulampot sehingga bisa meminimalisasi pengeluaran bulanan sehingga bisa meningkatakan kesejahteraan keluarga. Kegiatan ini dibagi menjadi tiga tahap. Tahap pertama tentang mengelola sampah dan membuat karya, tahap kedua menanam dilahan sempit dan yang ketiga yaitu pembentukan kader posdaya khususnya kader lingkungan. Kader diperlukan untuk selalu memotivasi masyarakat sehingga kegiatan-kegiatan kemasyarakatan dapat berjalan dengan baik.

Dengan kegiatan ini, tim mempunyai harapan besar supaya komplek perumahan ACR bisa menjadi komplek yang bersih, rapi, sehat dan nyaman. Selain itu bisa menjadi komplek mandiri wiyata yaitu komplek perumahan yang baik dalam pengelolaan sampah dan lingkungannya. Dengan kegiatan ini bisa membuat semangat para ibu-ibu dalam 
membuat karya yang bisa menghasilkan dan bisa memperbaiki gizi keluarga dengan pemanfaatan pekarangan untuk berkebun, sehingga pada akhirnya akan tercipta kesejahteraan keluarga. Dengan kegiatan ini bisa melahirkan banyak kader-kader lingkungan yang loyal sehingga terjaga keberlanjutan kegiatankegiatan baik dalam upaya peningkatan mutu sumberdaya manusia dan lingkungan.

Kegiatan pengabdian masyarakat dengan tema seperti ini yang terkesan biasa saja akan tetapi jika banyak perumahan/komplek dan masyarakat mengaplikasikan maka akan bisa menciptakan kota wiyata yang bisa dalam jangkauan yang besar akan membantu dalam berpartisipasi menjaga bumi yang semakin lama semakin tua.

\section{Luaran}

Sementara luaran yang bersifat fisik antara lain pembuatan tutorial tentang membuat karya dengan teknik decoupage, poster tentang penggolongan sampah organik, anorganik, dan bahan kimia, spanduk di fasum himbauan untuk membuang sampah pada tempat sampah. Selain tentang sampah, juga akan membuat poster tentang cara membuat kompos, menanam dilahan sempit dan buku pos daya. Sedangkan luaran lain yaitu produk-produk hasil karya ibu-ibu, sehingga luaran yang bersifat keterampilan juga didapat.

\section{DAFTAR PUSTAKA}

Suyono, H. dan Haryanto, R. (2007). Buku Pedoman Pembentukan dan Pengembangan Pos Pemberdayaan Keluarga. Jakarta : Balai Pustaka.

Trihadiningrum, $\quad$ Y.. (2008). Perkembangan Paradigma Pengelolaan Sampah Kota Dalam Rangka Pencapaian Millenium Development Goals. Sumber: http://webcache.googleus ercontent.com/www.unhas.ac.id/

UURI No. 18/2009. Pengelolaan Sampah 